\title{
PHYSICAL ANTHROPOLOGY AND BIOARCHAEOLOGY AT THE INSTITUTE OF HISTORY IN THE LAST 20 YEARS
}

\author{
Raili Allmäe, Jana Limbo-Simovart, Leiu Heapost \\ Archaeological Research Collection, Tallinn University, Tallinn, Estonia
}

\begin{abstract}
Human populations and their history have been studied at the Institute of History since 1952 when the young researcher Karin Mark started her career here. Later, Karin Mark became a leading researcher in palaeoanthropology and somatology of Finno-Ugric peoples, and her working group grew. At the end of the 1980s, Leiu Heapost took over the position as group leader in anthropological research. In 1988 Raili Allmäe and in 2004 Jana Limbo-Simovart joined the group. Since 1998, Estonian research has been project-based; in the present paper we give a brief overview of our anthropological research at the Institute of History (and its descendants) in the last twenty years.
\end{abstract}

Keywords: Institute of History; physical anthropology; Estonia; bioarchaeology; human populations

\section{INTRODUCTION}

Past and modern human populations have been studied at the Institute of History since 1952 when young researcher Karin Mark started her career here. Later, Karin Mark became a leading researcher in palaeoanthropology and somatology of Finno-Ugric peoples [42], and her working group grew. In present paper, we give an overview of the research conducted by the group of anthropologists who have worked at the Institute of History (at Tallinn University) during the last two decades. The group has three members: Leiu Heapost, $\mathrm{PhD}$, Raili Allmäe, PhD, and Jana Limbo-Simovart, MSc. In the following sections, we will present the research projects we have been involved in, our main fields and topics of research and scientific output and also describe the communication of our research to the society. 


\section{MAIN PROJECTS}

There are three Estonian target-financed research projects and several grants financed by the Estonian Science Foundation where our group of anthropologists was involved during 1998-2013. All target-financed projects dealt with a wide range of issues concerning interactions between humans and environment: 1998-2002, Man, environment, technology. Development of the exploitation of natural resources and the technological idea during the prehistoric and historical times in Estonia (AI0040009s98), 2003-2007, Interactions between the natural environment and man from the geographical, historical and technological aspect (SF0042476s03), and 2008-2013, Reflection of the development of human society in natural environment, ancient technology and archaeobiological material, and its tracing by interdisciplinary methods (SF0130012s08). The smaller-scale projects financed by the Estonian Science Foundation dealt with specific problems, like cremation burials (1998-2002, Mati Mandel, Museum of History, Western Estonian burial grounds of the $5^{\text {th }}-13^{\text {th }} c c$.; 2004-2007, Mare Aun, Institute of History, The antiquities of long barrows culture of North Setumaa, and methodological issues (2006-2009, Lembi Lõugas, Institute of History, Introduction of new methods in osteo-archaeological research).

Since 2014, anthropological research at the Institute of History and (its descendants) at Tallinn University has been financed mainly by small grants offered by the Research Fund of Tallinn University. Also, the project Viking phenomenon funded by the Swedish Research Council has contributed to anthropological research in the last two years.

\section{MAIN FIELDS OF RESEARCH AND PUBLICATIONS}

The research has covered human skeletal samples from Stone Age to the present, but it has also dealt with living populations. The main research fields have been population studies of Estonians and neighbouring countries, developmental studies based on archaeological and living populations, population genetics, human health and physiological stress, human-environment interaction in the past, forensic anthropology cases from the 20th century, investigation of archaeological mass graves and commingled human remains, palaeodemography.

The focus of Leiu Heapost's research during the last decades has been somatology and bioarchaeology, languages and genes, the population-genetic structure of Estonians and the position of the Estonian population among European and Finno-Ugric peoples. Among these topics, the preparation of 
the book Physical Anthropology of Finno-Ugric Peoples by Karin Mark and Leiu Heapost has been most crucial and challenging. Leiu Heapost has participated in several scientific conferences in Europe, especially in Russia and Belarus. Her thesis has contributed to the discussion on body height in Estonia in the past [31], to the discussion on the anthropological formation of the Estonian population [32, 34], to the history of Estonian anthropological research [37], to the bioarchaeology of the Viski people in Pskov [38], to the morphology of Eurasian people [39], to the developmental biology [41]. During 1998-2017, Leiu Heapost published 56 research papers, among which the author highlights the ones dealing with body height of Estonians throughout the times $[29,30]$ and bioarchaeology of Siksälä population [33]. Among co-authored papers, the first contributes to the discussion on racial identity and physical anthropology [45], and the second to the discussion on bone chemistry [44]. Papers of considerable importance also dealt with population genetic characterization of Estonians and other Eurasian populations [26, 27, 28]. Lately, the author has mostly focused on Finno-Ugric peoples, including a substantial book on physical anthropology of Finno-Ugric peoples [35, 36, 43, 54, 40].

The focus of Raili Allmäe's research has been on bioarchaeology and population studies, population history, analysis of cremated and commingled skeletal materials, palaeodemography, investigation of archaeological mass graves, human and environment interaction, skeletal trauma, skeletal stress-markers, forensic cases from WWI, WWII and post-war terror victims. Presentations at international conferences in different countries have addressed topics as ethnical composition of Pärnu garrison [9], Iron Age cremation graves in Estonia [5, 7, 8, 15], sharp force trauma [16] and forensic cases of Red Terror victims [24]. From 1998-2017, Raili Allmäe published 68 research papers, among which the papers dealing with osteological analysis of cremation burials, first radiocarbon datings of cremated bones in Estonian graves, and demography of Iron Age graves should probably be emphasised [4, 6, 11, $58,14,17]$. The research was finalised with the defence of her doctoral thesis [18]. The most voluminous part of papers concerns bioarchaeological analysis of different skeletal materials, among which her earlier works should be mentioned $[1,2,3]$. The initial research of human skeletal remains collected from Salme ship-graves should also be noted $[12,21,55,56]$. In cooperation with colleagues, we have experimented with bone chemistry [22], studied skeletal stress-markers $[10,20]$, tested conventional ageing and sexing methods [23, 24], resolved the question of the origin of men from Salme ships [57], and shed light on the early history of plague [25]. 
Jana Limbo-Simovart's research has focussed on odontology, relations between environment and humans, human health, genetic background of populations; she has studied oral and dental pathologies and stress-markers, and also dealt with methodological issues. She has used dental metric and descriptive features to study health and well-being of human populations. Jana Limbo-Simovart's presentations at international conferences have contributed to the discussions on dental health and stress-markers $[49,50]$ and to methodological issues [51, 52]. From 2004-2017, Jana Limbo-Simovart published 28 research papers. The author emphasises the papers dealing with dental pathologies and stress-markers [46, 47, 48, 19, 20, 52, 53], and also joint papers on bone chemistry and on forensic cases $[22,23]$.

\section{ORGANIZATIONAL ACTIVITIES AND COMMUNICATION TO SOCIETY}

Joint activities of the anthropological research group at the Institute of History have been arrangement of conferences and numerous seminars. The first significant conference was organized in 2007 to celebrate the $85^{\text {th }}$ anniversary of our famous anthropologist Karin Mark. For this purpose, we compiled an exhibition and arranged the conference Karin Mark 85. 55 years of anthropology at the Institute of History. The exhibition presented an enormous amount of unique somatological data collected from Finno-Ugric people on numerous expeditions Karin Mark conducted during her career at the Institute. The anthropologists' equipment and many original instruments made by Karin Mark herself were also on display for the first time. The conference covered many topics intriguing for archaeologists, historians, molecular biologists, linguists and anthropologists. (In Estonia of the 1980s, the term 'anthropologist' mainly referred to a physical anthropologist, cultural anthropologists were known as ethnologists then). There were presentations to commemorate Karin Mark as a researcher and a colleague, to understand her extraordinary scientific legacy and the purpose of her life-long research. The main themes of presentations were archaeology, ethnos and ethnicity, archaeogenetics, linguistics and philology, and, naturally, physical anthropology and development of natural-science-based research at the Institute of History since the 1950s. The presenters were top researchers in their fields Lembit Jaanits, Ants Viires, Leiu Heapost, Heiki Valk, Siiri Rootsi, Kristiina Tambets, Karl Pajusalu, etc.

Karin Mark's conference developed into the annual seminar (Karin Mark Day) on physical anthropology and related research at the Institute of History. In 2008-2013, were arranged six seminars on quite intriguing themes. 
In 2008, the seminar Physical anthropology and skeletal populations was held on 24 March. Leiu Heapost, Jana Limbo, Ingrid Õunapuu, Ülle Aguraijuja and Raili Allmäe introduced their work with human skeletal remains collected from single and mass graves of 14th-18th centuries cemeteries.

In 2009, the seminar Sexual determination and dimorphism, culture and human behaviour was held on 23 March. What do we know about sexual selection and dimorphism in humans? How is sexual dimorphism formed in animals? The lectures were Mart Viikmaa, Peeter Hõrak and Gudrun Veldre from the University of Tartu.

In 2010, the seminar Biological sex and gender/sex roles was held on 9 April. What is sex and what is gender? How do different disciplines define sex/ gender? The lectures were Ene-Margit Tiit and Gudrun Veldre from the University of Tartu, Markku Niskanen from the University of Oulu, Mirja Ots and Jana Limbo-Simovart from Tallinn University.

In 2011, the seminar Different sources and ways to study humans was held on 18 March. There are several sources and ways to study humans and interaction between humans and environment. The lecturers were Mart Viikmaa and Ken Kalling from the University of Tartu, and Heidi Luik and Maie Pihlamägi from Tallinn University.

In 2012, the seminar Eating is inevitable. Food today and in the past was held on 23 March. The lecturer were the researchers who study human food, subsistence strategies and how this is manifested in skeletal remains. The lecturers were mostly from Tallinn University: Inna Põldsam-Jürjo, Lembi Lõugas, Leiu Heapost, Raili Allmäe, Jana Limbo-Simovart, Liina Maldre, Sirje Hiie and Ülle Sillasoo, and Professor Selma Teesalu from Tartu.

In 2013, the seminar Disease as misfortune was held on 25 March. What is normality, what is pathology? How does disease form, how was it treated in the past? How can we identify disease from bones and teeth? The lecturers were Marju Kõivupuu and Jana Limbo-Simovart from Tallinn University, Martin Malve and Gudrun Veldre from the University of Tartu, and Piret Viiklepp from the National Institute of Health Development.

On 21-24 August in 2011, we had the honour of arranging the second meeting of bioarchaeologists from the countries around the Baltic Sea (BBM 2011). The theme of the conference was Past people around the Baltic Sea [13]; we had 40 participants from eight countries. Various topics in the fields of archaeogenetics, population genetics, epidemiology, palaeopathology, palaeodemography, bone chemistry, archaeology, osteoarchaeology and, naturally, physical anthropology and population history were discussed. 
The anthropologists of the Institute of History have held occasional courses and lectures on physical anthropology and bioarchaeology at Tallinn and Tartu University, and also supervised students' theses. Probably the most noteworthy course was organized by Raili Allmäe for archaeology students at the University of Tartu in 2007 - an intensive course on bioarchaeology, with contribution by Professor Rimantas Jankauskas (Vilnius University) and Jana Limbo-Simovart (Tallinn University).

The anthropologists from the Institute of History have always participated in the events organized to celebrate Professor Juhan Aul's birth anniversaries, at the seminars arranged by the Estonian Naturalists' Society and the Centre for Physical Anthropology. All these events enable us to communicate our research results on bioarchaeology and physical anthropology to society. Additionally, all team members have communicated their work in written, audible and visual media. For example, Leiu Heapost has a very popular lecture in One Minute Lecture series; in print media (Õpetajate Leht), Jana Limbo-Simovart has discussed the anthropologist's role in society, and Raili Allmäe has lectured on militant Vikings at the Maritime Museum.

\section{SUMMARY}

The research results of the members of the physical anthropology group at the Institute of History, Tallinn University, in the last decades:

- have participated in more than 20 research projects;

- have published more than 150 research papers and theses;

- have presented their research at numerous international conferences and seminars in Riga, Tartu, Tallinn, Kuressaare, Minsk, Moscow, Pskov, Jena, Vilnius, St Petersburg, Helsinki, Stockholm, Lund, Uppsala, Copenhagen, Odense, Budapest, Brussels.

- have arranged several scientific seminars and conferences;

- have been involved in teaching of physical anthropology and bioarchaeology;

- have popularized physical anthropology and bioarchaeology in visual, audible and written media.

More information on our research is available in the Estonian Research Information System s://www.etis.ee/ 


\section{REFERENCES}

1. Allmäe R. (1998). Tääksi 14.-18. sajandi populatsiooni demograafiline analüüs ja kehapikkuse rekonstrueerimine. V. Lang (toim.). Loodus, inimene ja tehnoloogia: interdistsiplinaaarseid uurimusi arheoloogias = Nature, man and technology: interdisciplinary studies in archaeology. Tallinn: Eesti TA Ajaloo Instituut. (Muinasaja Teadus, 5), 163-187.

2. Allmäe R. (1999a). Dental and cranial pathologies in Tääksi 14th-18th cc. skeletal population. Papers on Anthropology, VIII, 9-14.

3. Allmäe R. (1999b). Tääksi 14.-18. sajandi populatsiooni mõnedest odontoloogilistest tunnustest. Eesti Antropomeetriaregistri Aastaraamat $=$ Yearbook of the Estonian Anthropometric Register. Tartu: Tartu Ülikool, 25-37.

4. Allmäe R. (2003). Läänemaa 5.-13. sajandi kalmete antropoloogiline aines. In: Mandel, M. Läänemaa 5.-13. sajandi kalmed. Tallinn: Eesti Ajaloomuuseum. (Töid ajaloo alalt, V), 243-262.

5. Allmäe R. (2004). Cremations of western Estonia in 5th-13th cc. In: International Scientific Conference "200 Years of Lithuanian Anthropology: Modern Trends, History, Relation to Medical Practice and Humanities”. Vilnius, 26.

6. Allmäe R. (2006). Grave 2 of Maidla - the burial site of a single family. Eesti Arheoloogiaajakiri = Estonian Journal of Archaeology, 10 (1), 3-23.

7. Allmäe R., Aun M., Maldre L. (2007a). Predvaritel'nye rezul'taty izučenija osteoličeskogo materiala kurgannyh mogil’nikov Rõsna-Saare I i II v Severnoj Setumaa (Jugo-Vostočnaja Ėstonija). Arheologija i istorija Pskova i Pskovskoj zemli. Seminar imeni akademika V. V. Sedova. Materialy LII zasedanija, posvjaštšennogo pamjati professora A. R. Artem'jova. Pskov = Аллмяэ P., Аун М., Малдре Л. (2007a). Предварительные результаты изучения остеолического материала курганных могильников Рысна-Сааре I и II в Северной Сетумаа (Юго-Восточная Эстония). Археология и история Пскова и Псковской земли. Семинар имени академика В. В. Седова. Материалы LII заседания, посвященного памяти профессора А. Р. Артемьева. Псков, 298-310.

8. Allmäe R., Aun M., Maldre L. (2007b). Cremations of The Culture of Long Barrows in Northern Setumaa in the Second Half of the First Millennium. Preliminary results. Humanbiologia Budapestinensis, 30, 113-122.

9. Allmäe R. (2008a). Pärnu garrison and its varied origin. 16th Congress of the European Anthropological Association: Abstracts: 16th Congress of the European Anthropological Association, Odense, August 28-31, 2008. Denmark: University of Southern Denmark, 34.

10. Allmäe R. (2008b). The stature and sexual dimorphism on the basis of skeletal materials of the16th-18th century Pärnu garrison. Papers on Anthropology, $17,15-27$. 
11. Allmäe R. (2010). Some remarks on Kaseküla stone-cist grave, Läänemaa, Estonia. Fennoscandia Archaeologica, XXVII, 45-52.

12. Allmäe R. (2011). Men in Salme boat-graves. Baltic Bioarchaeology Meeting. Programme and Abstracts. Past People Around the Baltic Sea. August 21-24, 2011, Tallinn, Estonia. Ed. Allmäe R., Heapost L., Limbo-Simovart J. Tallinn: Tallinna Ülikooli Ajaloo Instituut, 10.

13. Allmäe R., Heapost L., Limbo-Simovart J. (eds.) (2011). Baltic Bioarchaeology Meeting. Past People Around the Baltic Sea. Programme and Abstracts. August 21-24, 2011, Tallinn, Estonia. Tallinn: Tallinna Ülikooli Ajaloo Instituut.

14. Allmäe R. (2013) Observations on Estonian Iron Age cremations. Archaeologia Baltica, 19, 31-47. https://doi.org/10.15181/ab.v19i0.272

15. Allmäe R. (2014a). On Iron Age cremation graves in Estonia. 3rd Baltic Bioarchaeology Meeting: Programme and Abstracts.: Baltic Bioarchaeology Meeting, 14-17 May 2014, Riga, Latvia. Riga, Latvian University, 10.

16. Allmäe R. (2014b). Salme II ship-grave: examples of edged weapon injuries. Programme and Abstracts: 20th European Meeting of the Palaeopathology Association. Lund, Sweden. 26th-31st August 2014. Lund: Lund University, 13.

17. Allmäe R. (2014c). The Demography of Iron Age graves In Estonia. Lietuvos archeologija, 40, 103-120.

18. Allmäe R. (2017). Iron Age cremation burials in South-Eastern and West Estonia. An osteological approach. Tallinn University, School of Humanities.

19. Allmäe R., Limbo J. (2008). 16.-18. sajandi Pärnu garnisoni kalmistule maetute antropoloogiast. Pärnumaa. 1. köide. Loodus. Aeg. Inimene. Eesti Entsüklopeediakirjastus.

20. Allmäe R., Limbo J. (2010). Skeletal stress-markers in the early modern town of Pärnu, Estonia. Papers on Anthropology, 19, 29-48.

21. Allmäe R., Maldre L., Tomek T. (2011). The Salme I ship burial: An osteological view of a unique burial in Northern Europe. Interdisciplinaria Archaeologica, 2 (2), 109-124. https://doi.org/10.24916/iansa.2011.2.4

22. Allmäe R., Limbo-Simovart J., Heapost L., Verš E. (2012). The content of chemical elements in archaeological human bones as a source of nutrition research. Papers on Anthropology, 21, 27-50. https://doi.org/10.12697/poa.2012.21.03

23. Allmäe R., Limbo-Simovart J. (2015). Conventional ageing and sexing methods based on teeth and dry bone morphology in the person's identification (victims of Red Terror in 1946). Papers on Anthropology, 24 (2), 19-26. https://doi.org/10.12697/poa.2015.24.2.02

24. Allmäe R., Limbo-Simovart J., Unt A. (2017). The story of Red Terror victims: multidisciplinary approach. Baltic Morphology IX. Conference programme. Abstracts of presentations. Baltic Morphology IX, Tartu, 27.-29.09.2017. Ed. Arend A., Aunapuu M. Tartu: Tartu Ülikool, 62. 
25. Andrades Valtuena A., Mittnik A., Key F. M., Haak W., Allmäe R., ... Krause J. (2017). The Stone Age plague and its persistence in Eurasia. Current Biology, 27, 1-9. https://doi.org/10.1016/j.cub.2017.10.025

26. Heapost L. (1998). Genetic heterogeneity of Finno-Ugrians (on the basis of Estonian modern and archaeological material). Baltic-Pontic Studies, 5, 232-247.

27. Heapost L. 2000. A population genetic characterization of Estonians. Anthropologischer Anzeiger, 58 (2), 137-154.

https://doi.org/10.1127/anthranz/58/2000/137

28. Heapost L. 2001. Baltic Finns and Indo-Europeans. An anthropological aspect. FU 9, Pars VIII. Tartu, 2001, 278-283.

29. Heapost L. 2002. Saarlaste antropoloogiast. Saaremaa. I osa. Loodus, aeg, inimene. (toimetajad H. Kään, H. Mardiste, R. Nelis, O. Pesti). Tallinn, 557- 594.

30. Heapost L. 2003. Variation of stature in Estonia from the 12th to the 20th centuries. Papers on Anthropology, 12, 51-61.

31. Heapost L. (2006a). Izmenenie dliny tela naselenija Èstonii ot XII do XX veka. Aktual'nye voprosy antropologii: Genetičeskie i morfologičeskie markery v antropologii, kriminalistike i medicine (15-17 ijunja 2005 g., Minsk). Red. Lokotko A.I. = Хеапост Л. (2006). Изменение длины тела населения Эстонии от XII до XX века. Актуальные вопросы антропологии: Генетические и морфологические маркеры в антропологии, криминалистике и медицине (15-17 июня 2005 г., Минск). Ред. Локотко А.И. Minsk, 156-160.

32. Heapost L. (2006b). The population of SE corner of Estonia at the end of the Iron Age and in the Middle Ages. Acta Medica Lituanica, 13, 2, 109-114.

33. Heapost L. (2007). The cemetery of Siksälä: osteological and paleodemographical analysis. Laul S., Valk H. (ed.). A Community at the Frontiers. Iron Age and Medieval. Tallinn-Tartu: University of Tartu, 213-236.

34. Heapost L. (2008a). Ètnokul'turnyj fon antropologičeskogo formirovanija jugo-vostočnyh èstoncev v XI-XV vv. Aktual'nye voprosy antropologii, 2: Aktual'nye problemy fizičeskoj i sociokul'turnoj antropologii. Minsk, 19-21 ijunja 2007. Meždunarodnaja naučno-praktičeskaja konferencija. Red. L.I. Tegako, I.I. Salivon i dr. Minsk = Хеапост Л. (2008a). Этнокультурный фон антропологического формирования юго-восточных эстонцев в XI$\mathrm{XV}$ вв. Актуальные вопросы антропологии, 2: Актуальные проблемы физической и социокультурной антропологии. Минск, 19-21 июня 2007. Международная научно-практическая конференция. Ред. Л.И. Тегако, И.И. Саливон и др. Минск, 290-295.

35. Heapost L. (2008b). Izmenčivost' cveta glaz i volos u finno-ugorskih narodov. A.P. Bužilova i dr. Aktual'nye napravlenija antropologii. Moskva: Rossijskaja akademija nauk = Хеапост Л. (2008b). Изменчивость цвета глаз и волос у 
финно-угорских народов. А.П. Бужилова и др. Актуальные направления антропологии. Москва: Российская академия наук, 222-227.

36. Heapost L. (2008c). Pigmentation variation in Finno-Ugric peoples. Papers on Anthropology, 17, 80-102.

37. Heapost L. (2010). On the history of anthropological research in Estonia. Historiae Scientiarum Baltica. Abstracts of the XXIV International Baltic Conference on the History of Science: The XXIV International Baltic Conference on the History of Science, Tallinn, October 8-9, 2010. Ed. M. Talts, K.L. Linask. Tallinn University of Technology, 72-73.

38. Heapost L. (2011). K bioarheologii mogil'nika Viski v XIV-XV vv. Arheologija i istorija Pskova i Pskovskoj zemli. Pskov, 7-9 aprelja, 2010. Pskov: Rossijskaja akademija nauk = Хеапост Л. (2011). К биоархеологии могильника Виски в XIV-XV вв. Археология и история Пскова и Псковской земли. Псков, 7-9 апреля, 2010. Псков: Российская академия наук, 77-86.

39. Heapost L. (2013). On morphology of the Eurasian peoples. Baltic Morphology VII Scientific Conference Abstract Book: Morphological Sciences in the Experimental and Clinical Medicine; Riga, Latvia; November 7-9, 2013. Riga Stradinš University, 28.

40. Heapost L. (2016). We and the others: Physical anthropology of Finno-Ugric peoples. Papers on Anthropology, 25 (1), 93-103.

https://doi.org/10.12697/poa.2016.25.1.10

41. Heapost L. (2017). On the development of descriptive anthropological traits of schoolchildren. Baltic Morphology IX. Conference programme. Abstracts of presentations. Baltic Morphology IX, Tartu, 27.-29.09.2017. Ed. Arend A., Aunapuu M. Tartu: Tartu Ülikool, 67.

42. Heapost L., Allmäe R., Limbo J. (2008). 85 years from birth of the Estonian anthropologist Karin Mark. Anthropologischer Anzeiger, 66 (2), 247-252. https://doi.org/10.1127/aa/66/2008/247

43. Heapost L., Mark K. (2010). Ethnic and geographical variability of Finno-Ugric peoples' stature. Papers on Anthropology, 19, 94-109.

44. Heapost L., Allmäe R., Limbo-Simovart J., Verš E. (2014a). Soderžanie himičeskih èlementov v kostnyh ostankah ljudej iz arheologičeskih raskopok v Èstonii. Polina, N. Aktual'nye voprosy antropologii, 9 (23-32). Minsk: Belaruskaja navuka = Хеапост Л., Аллмяэ Р., Лимбо-Симоварт Я., Верш Э. (2014a). Содержание химических элементов в костных останках людей из археологических раскопок в Эстонии. Полина, Н. Актуальные вопросы антропологии, 9 (23-32). Минск: Беларуская навука.

45. Kalling K., Heapost L. (2013). Racial Identity and Physical Anthropology in Estonia 1800-1945. In: Felder B., Weindling P. (ed.). Baltic Eugenics. BioPolitics, Race and Nation in Interwar Estonia, Latvia and Lithuania Amsterdam: Rodopi, 83-114. https://doi.org/10.1163/9789401209762_006 
46. Limbo J. (2004a). Pada kalmistu indiviididel esinevad hambapatoloogiad (XIIXIII sajand). Eesti Arheoloogiaajakiri = Estonian Journal of Archaeology, 8 (1), 49-75.

47. Limbo J. (2004b). Dental pathologies of male and female in Pada cemetery (12th-13th century). Papers on Anthropology, 13, 134-144.

48. Limbo J. (2006). Dental enamel hypoplasia in Pada cemetery (12th-13th cc.) population in Northeast Estonia. Papers on Anthropology, 15, 114-123.

49. Limbo-Simovart J. (2008a). Dental Enamel Hypoplasia in the 17th-18th cc. town population from Pärnu, Estonia. "16th Congress of the European Anthropological Association. Abstracts": 16th Congress of the European Anthropological Association. Odense, August 28-31, 2008. Denmark: University of Southern Denmark, 97.

50. Limbo J. (2008b). Dental pathologies and stress markers in the Iron Age end/ early medieval in Estonia. Aktual'nye napravlenija antropologii. Sbornik posvjaštšennyj 80-letiju akademika RAN T.I. Alekseevoj: “Adaptacija kak faktor formirovanija antropologičeskogo svoeobrazija drevnego i sovremennogo naselenija Evrazii” Moskva, 8-9 dekabrja 2008 g. = Актуальные направления антропологии. Сборник посвященный 80-летию академика РАН Т.И. Алексеевой: «Адаптация как фактор формирования антропологического своеобразия древнего и современного населения Евразии» Москва, 8-9 декабря 2008 г. Ed. A.P. Bušilova, M.V. Dobrovolskaja, M.B. Mednikova. Moskva: Институт Археологий РАН, 162-164.

51. Limbo J. (2009). Fragmented commingled human bones of migration period (450-600 AD) mortuary house at Lepna Saaremaa (Ösel Island), Estonia: possible use of teeth. Baltic Bioarchaeology Meeting. Bioarchaeology and Forensic Anthropology.: Baltic Bioarchaeology Meeting. Vilnius, Lithuania. 23.-26. August, 2009. Ed. Pauliukevicius A., Caplinskiene M., Damijonaitiene R., Jankauskas R. Vilnius: UAB “Utenos Indra”, 22.

52. Limbo J. (2011). The attrition of deciduous teeth and dental age in Estonian skeletal samples. Baltic Bioarchaeology Meeting. Past People Around the Baltic Sea: Baltic Bioarchaeology Meeting 2011, Tallinn, August 21-24, 2011. Ed. Allmäe R., Heapost L., Limbo J. Tallinna Ülikooli Ajaloo Instituut, 20.

53. Limbo-Simovart J. (2013). The frequency and pattern of dental caries in archaeological populations from Estonia. Papers on Anthropology, 22, 121-132. https://doi.org/10.12697/poa.2013.22.13

54. Mark K., Heapost L. (2014b). Soome-ugri rahvaste füüsiline antropoloogia. Tallinn: Eesti Teaduste Akadeemia Kirjastus.

55. Peets J., Allmäe R., Maldre L. (2011). Archaeological investigations of PreViking Age burial boat in Salme village at Saaremaa. Arheoloogilised välitööd Eestis = Archeological fieldwork in Estonia, 2010, 29-48. 
56. Peets J., Allmäe R., Maldre L., Saage R., Tomek T., Lõugas L. (2013). Research results of the Salme ship burials in 2011-2012. Arheoloogilised välitööd Eestis $=$ Archeological fieldwork in Estonia, 2012, 43-60.

57. Price T.D., Peets J., Allmäe R., Maldre L., Oras E. (2016). Isotopic proveniencing of the Salme ship burials in pre-Viking Age Estonia. Antiquity, 90 (352), 1022-1037. https://doi.org/10.15184/aqy.2016.106

58. Valk H., Allmäe R. (2010). Kirikumägi at Siksälä: evidence of a new grave form of South-Eastern Estonia. Estonian Journal of Archaeology, 14 (1), 40-55. https://doi.org/10.3176/arch.2010.1.03

\section{Address for correspondence:}

Raili Allmäe

Archaeological Research Collection,

Tallinn University

Rüütli 6, Tallinn 10130, Estonia

E-mail: raili.allmae@tlu.ee 